\title{
Human Capital and Economic Growth in Pakistan: A Cointegration and Causality Analysis
}

\author{
Nabila Asghar \\ Ph.D. Scholar, Department of Economics, GC University, Faisalabad, Pakistan \\ Tel: 92-300-434-8225 E-mail: Nabilakhan83@gmail.com
}

Asma Awan

Ph.D. Scholar, Department of Economics, University of the Punjab, Lahore, Pakistan

Tel: 92-334-420-1668 E-mail: asma.awan1@yahoo.com

Hafeez ur Rehman (Corresponding author)

Chairman/Professor, Department of Economics, University of the Punjab, Lahore, Pakistan

Tel: 92-42-9923-1167Ｅ-mail: drhrehmankhan@gmail.com

Received: October 13, $2011 \quad$ Accepted: February 13, $2012 \quad$ Published: April 1, 2012
doi: $10.5539 /$ ijef.v4n4p135

\begin{abstract}
This study is an attempt to investigate the role of human capital in terms of education and health on economic growth of Pakistan during 1974-2009. Using annual data, ADF, PP and Ng-Perron tests are utilized to check the stochastic properties of the variables. Long-run relationship among variables is confirmed through Johansen and Juselius cointegration test whereas the long-run and short-run dynamics are observed by VECM specification. For causality purpose both VECM based causality and Toda-Yamamoto causality tests are employed. Stability of the model is confirmed through CUSUM and CUSUMSQ. The results indicate strong positive impact of human capital on economic growth despite the fact that Pakistan has been spending less percentage of GDP on education and health facilities to create human capital. The study concludes that in order to reap maximum benefits from human capital there is a need to formulate and implement effective economic policies related to the provision of education and health facilities to the people.
\end{abstract}

Keywords: Economic growth, Human capital, Education and health

JEL classification: F43, J24, I21, I11

\section{Introduction}

Sustained economic growth accompanied with social development is one of the notable macroeconomic objectives of every country and in this regard human capital is deemed as an essential ingredient. The initial theory of human capital dates back to pioneer work of Mincer (1958), Schultz (1961) and Becker (1962), who believe that human capital is just like physical capital and one can invest in it by means of education, health and training which, in turn, will raise output and contribute to economic growth. Furthermore, proponents of endogenous growth theory lay emphasis on human capital formation and regard it a factor which explains difference in growth performance of under developed and developed nations (for details, see, Romer, 1986, 1990; Lucas, 1988; Rebelo, 1991). Therefore, it can be concluded that human capital has gained significant importance in growth theories. However, its measurement is not addressed properly in economic literature. Various researchers have utilized different proxies for human capital, e.g. Mankiew et al. (1992) utilize secondary education enrollments. Barro and Lee (1993) and Bosworth et al. (1995) have used average years of schooling. The existing literature on human capital reveals that while acknowledging the role of human capital in economic growth macroeconomists express human capital solely in the form of education whereas microeconomists consider health as another important component of human capital beside education. They believe that health plays significant role in the formation of human resources because in order to ensure growth in productivity, people need to be healthy or protected from sickness. It means health and education both are primary ingredients of human capital formation. 
The government of Pakistan has failed to reap the maximum benefits from human capital due to less emphasis and less budget allocation to social sector. Despite almost threefold increase in total expenditure of public sector since 2001, the government spending on health and education has remained low. In fact spending on health as a percentage of GDP has even declined over time as it was $0.72 \%$ of GDP in 2001 which declined to $0.54 \%$ of GDP in year 2009. In terms of education spending Pakistan is one of the lowest in the South Asia and in terms of human development index latest ranking of 2010, Pakistan ranked at $125^{\text {th }}$ position whereas India ranked at $119^{\text {th }}$ position, Maldives ranked at $107^{\text {th }}$ position; Sri Lanka ranked at $91^{\text {st }}$ position. The two other countries of the region, i.e. Bangladesh and Nepal, are considered to be low human developed nations and ranked at $129^{\text {th }}$ and $138^{\text {th }}$ respectively.

It is pertinent to highlight that since the past decade human capital development is highly prioritized in Pakistan and the national education and health policies are aimed at improving these sectors and for achieving MDGs (Millennium Development Goals) especially in health by 2015. The improvement in certain health indicators and in literacy rate have been observed during the past decade but overall it ranked poorly in this context. Regional comparison in terms of human development index and human capital indicators (education and health) during 1980-2009 is reported in the Table 1.

Table 1 shows that Pakistan's spending on education has improved over time but still it spends less percentage of GDP on education. However, improvement in literacy rate has been observed over the years, which in turn has contributed to economic growth but over all it still ranks poor in the world in terms of education. Health spending as a percentage of GDP has been low in Pakistan but during last two decades special attention has been given to provide health facilities to the people. As a result few positive outcomes have been observed, e.g. in terms of life expectancy (an indicator of health) it ranks better in the world and infant mortality rate at birth has also declined over the period. Hence, it can be concluded that not much improvement in education and health standards have been observed in Pakistan. Therefore, there is a dire urgency to invest more in human capital in the form of education and health for achieving sustained economic growth.

Most of the empirical research conducted on the subject matter on Pakistan economy has defined human capital in terms of education indicators or in terms of health indicators. These indicators alone fail to capture development and skills of the labor force; therefore, there is a need to conduct research on this aspect that uses much broader measure of human capital in the context of Pakistan economy. The present study is an attempt to use broader measure of human capital as it uses education index and health index as proxies for human capital. These indices are self-constructed and are based on methodology of UNDP (United Nations Development Program). For details, see Appendix I. Furthermore, this study uses more advanced econometric techniques (Toda-Yamamoto) for estimating the causal relationship between human capital and economic growth in Pakistan. To the best of our knowledge no study has used this causality test in analyzing the causal relationship between human capital and economic growth in Pakistan. The proper understanding of the relationship between human capital and economic growth enables policy makers to formulate and implement proper policies that may help in utilizing the human resources of the country properly.

The remaining study is organized as follows: section 1 throws light on empirical literature, section 2 presents research design, section 4 reports results and discussions and section 5 concludes the study with policy prescriptions.

\section{Literature Review}

During the past century, the focus of researchers remained on the impact of human capital on economic growth by increasing the facilities of education and health. A number of empirical studies have documented a strong and positive relationship between human capital and economic growth. However, this relationship between the variables remained ambiguous.

Schultz (1971) and Becker (1962) both have developed and analyzed growth models augmented with human capital and find significant positive association between economic growth and human capital formation. According to Pritchett (1996), empirical results of cross country macro studies are controversial and inconsistent whereas results of micro studies are consistent and both have shown positive impact of education and health (proxies for human capital) on individual's productivity and income.

Earlier cross country macro studies find significant positive impact of human capital (education) on economic growth, see for example, Barro, 1991; Kyriacou, 1991. World Bank's study "East Asian Miracle" in 1993 also highlights that growth in human capital has caused rapid development of East Asian countries. Rosenzweig (1990) points out that major determinant of high growth of developed countries and poor growth of under developed countries is difference in the human capital growth. Developed countries are characterized by high standards of living whereas developing countries are not. 
Sachs and Warner (1997) find quadratic relationship in health-growth nexus. They assert that improvement in health standards do improve economic growth, however, when human capital increases, economic growth also increases but at a decreasing rate. Stewart et al. (1998) try to explore human development and economic growth nexus using cross country statistics (including 35 to 76 developing countries) during 1970-92. They identify two chains, i.e. one from human development to economic growth and other from economic growth to human development. According to them, there exists strong two way causation in human development versus economic growth nexus, however, strength of the positive relationship running from economic growth to human development depends on female education and share of public expenditure in social services whereas income distribution and investment rate determine the strength of positive relationship running from human development to economic growth. According to Fogel (1994), during 1970s and 1980s approximately one third of Britain's GDP growth have been observed due to substantial improvement in health facilities.

According to Taniguchi and Wang (2003), education and health both cause each other and thus contribute in economic growth. Weil (2001) findings related to health-growth nexus further strengthen the importance of health for economic growth. The study concludes that $17-20 \%$ of variations in income across countries is due to differences in health status. Agiomirgianakis et al. (2002) conduct panel study (consisting of 93 countries) on subject matter and find significant positive long-run impact of education (primary, secondary and tertiary) on economic growth. Bloom et al. (2004) try to investigate the impact of human capital on economic growth. By utilizing, 2SLS approach they find that schooling and life expectancy both positively contribute to economic growth. Improvements in health standards are associated with increase in output due to increased labor productivity and capital accumulation. Seebens and Wobst (2003); Moser and Eliot (2005) both have asserted that in the long-run education (human capital) increases substantially household income as well as economic growth. However, other studies including Bils and Klenow (2000), Easterly and Levine (2001), Temple (2001), Bosworth and Collins (2003) have failed to establish positive association between human capital (years of schooling) and economic growth.

In case of Pakistan, most of the studies have used micro data on human capital. These studies conclude that education brings significant positive returns for wage earners (for details see Nasir and Nazil (2001); Behrman et al. (2008)). Using macro data in a comparative analysis of Pakistan and India, Abbas and Qaiser (2000) find overall significant and positive impact of human capital (school enrollment rates as a proxy) on economic growth during 1970-1994. They use higher secondary, secondary and primary enrolment rates for observing the role of education in economic growth. They employ OLS on standard growth model augmented with variables of enrolment rates. The results of the study reveal that primary enrolment rate has positive and significant impact on economic growth only in case of India. Human capital measured by secondary and higher secondary enrolment rates have positive and significant impact on economic growth in Pakistan. The study indicates that positive and significant impact of human capital on economic growth in both countries when production function augmented with effective labour input is used in estimation. Khan (2005) tries to analyze the relationship between human capital and economic growth in 72 developing countries for the period 1980-2002. The study concludes that countries which invested significantly in human capital have achieved higher returns in terms of economic growth.

Malik (2006) using OLS fails to find positive association between human capital and economic growth in Pakistan and when he uses 2SLS estimation technique the results are totally opposite. Peck and Abbas (2008) also find positive impact of education and health on output during 1960-2003. Qadri and Waheed (2011) investigate the impact of human capital on Pakistan's economic growth during 1978-2007 and find it a highly significant determinant of economic growth. They utilize health adjusted education indicator as a proxy for human capital in Cobb-Douglas production function rather defining human capital solely in terms of health or education. Khatak and Khan (2012) use analytical techniques, i.e. OLS and Johansen cointegration to investigate the impact of human capital in economic growth of Pakistan for the period 1971-2008. The results support significant positive association between secondary education and economic growth.

After reviewing empirical literature on the subject matter it is evident that in case of cross country studies empirical results remained inconclusive whereas in a single country analysis mostly studies support positive association between human capital and economic growth. However, it is observed that different studies have used different proxies for human capital and difference in measurement of human capital may be a source of bias in their empirical results. Furthermore, it can be concluded that earlier studies have used education as a proxy for human capital and more recent studies lay emphasis on both health and education as a proxy for human capital. The existing literature on Pakistan economy shows that appropriate proxies of human capital are not used along with recent advances in dynamic modeling. There exists a gap in the literature regarding the role of human capital on economic growth in Pakistan. The present study is an attempt to bridge this gap by analyzing the causal relationship between human capital and economic growth using recent advances in dynamic modeling and more appropriate proxies for human 
capital. The results of this study may be helpful for policy makers in designing appropriate policies giving priority to the development of human capital.

\section{Data Set and Model Specification}

This study has employed annual time series data covering 36 years from 1974-2009. Recent advances in dynamic modeling are used to observe the impact of human capital on economic growth in Pakistan. The data have been obtained from Pakistan Economic Survey (various issues), World Development Indicators and International Financial Statistics (IFS).

In order to investigate empirical association between human capital and economic growth following model is specified.

$$
l P C Y_{t}=\beta_{0}+\beta_{1} E I_{1 t}+\beta_{2} H I_{2 t}+\mu_{1 t}
$$

Where
$l P C Y_{t}=\log$ of per capita income (in $\$$ ) as a proxy for economic growth.
$E I_{1 t} \quad=\quad$ Education Index (first proxy for human capital).
$H I_{2 t}=$ Health Index (second proxy for human capital). For details, see Appendix I.

Expected signs of the variables are reported in parenthesis.

\section{Econometric Methodology}

\subsection{Unit Root Tests}

In literature, it has been established that most of the economic time series variables are non-stationary and the use of non-stationary time series leads to spurious regression which cannot be used for precise decision. As a first step of empirical analysis, the order of integration of the variables included in the model is determined by using standard tests like ADF, PP and Ng-Perron. Most of the studies use ADF and PP tests for determining the order of integration of the variables. These tests have some weaknesses that make the results somewhat unreliable. Dejong et al. (1992) state that due to their poor size and power properties both ADF and PP tests are not reliable for small sample data set. Ng-Perron test has the superiority over ADF and PP, that it gives more reliable results even for small sample data set.

\subsection{Cointegration Test}

Cointegration is a statistical property that describes long-run relationship of economic time series. Johansen (1988) proposed an approach to investigate long-run relationship among non-stationary variables. This study uses Johansen and Juselius (1990) cointegration approach for exploring long-run relationship between economic growth and human capital.

\subsection{Vector Error Correction Model}

Short-run and long-run dynamics among variables are captured through vector error correction model. It is a special case of restricted VAR for the variables that are integrated of order one as well as having long-run relationship. Engle and Granger (1987) and Toda and Phillips (1993) have shown that representation of VAR in first difference form is mis-specified when there exists cointegration among the variables therefore VECM is suggested for co-integrated systems. The major purpose of VECM is to indicate the speed of adjustment from short-run equilibrium to long-run equilibrium state. Following system of equations are formulated under the specifications of VECM.

$$
\begin{aligned}
& \Delta l P C Y_{1 t}=\alpha_{10}+\sum_{i=1}^{p} \alpha_{11, i} \Delta l P C Y_{1, t-i}+\sum_{i=1}^{p} \alpha_{12, i} \Delta E I_{2, t-i}+\sum_{i=1}^{p} \alpha_{13, i} \Delta H I_{3, t-i}+\lambda_{1} E C T_{t-1}+\varepsilon_{1 t} \\
& \Delta E I_{2 t}=\alpha_{20}+\sum_{i=1}^{p} \alpha_{21, i} \Delta l P C Y_{1, t-i}+\sum_{i=1}^{p} \alpha_{22, i} \Delta E I_{2, t-i}+\sum_{i=1}^{p} \alpha_{23, i} \Delta H I_{3, t-i}+\lambda_{2} E C T_{t-1}+\varepsilon_{2 t}
\end{aligned}
$$




$$
\Delta H I_{3 t}=\alpha_{30}+\sum_{i=1}^{p} \alpha_{31, i} \Delta l P C Y_{1, t-i}+\sum_{i=1}^{p} \alpha_{32, i} \Delta E I_{2, t-i}+\sum_{i=1}^{p} \alpha_{33, i} \Delta H I_{3, t-i}+\lambda_{3} E C T_{t-1}+\varepsilon_{3 t}
$$

Where $\Delta$ is the difference operator, $p$ is the optimal lag length, $E C T_{t-1}$ is the lagged residual term.

\subsection{VECM Based Causality}

According to Granger Representation Theorem, if two variables are co-integrated and first difference stationary then there is an existence of causality in either direction. The present study uses multivariate causality test to explore all channels of causal relationship. Causality in systems (co-integrated systems) can be established if and only if lagged error correction term $\left(\mathrm{ECT}_{\mathrm{t}-1}\right)$ that takes into account long-run dynamics and sum of the coefficients of the lagged variables that takes into account short run dynamics both are significant.

\subsection{Toda-Yamamoto Causality}

Toda and Yamamoto (1995) proposed causality test which is robust for cointegration and stationarity properties. They levied criticism on VECM based causality test that its results may not be correct because preliminary tests biases of cointegration and first difference stationarity can be a possible source of wrong inferences regarding causality. Following system of equations is proposed to check causality inferences under Toda-Yamamoto causality test and SUR (seemingly unrelated regression) technique is utilized to estimate the model because due to SUR estimation wald test experiences efficiency.

$$
\begin{aligned}
& l P C Y_{t}=\alpha_{1}+\sum_{i=1}^{k+d_{\max }} \beta_{1 i} l P C Y_{t-i}+\sum_{i=1}^{k+d_{\max }} \delta_{1 i} E I_{t-1}+\sum_{i=1}^{k+d_{\max }} \lambda_{1 i} H I_{t-i}+\mu_{1 t} \\
& E I_{t}=\alpha_{2}+\sum_{i=1}^{k+d_{\max }} \beta_{2 i} l P C Y_{t-i}+\sum_{i=1}^{k+d_{\max }} \delta_{2 i} E I_{t-1}+\sum_{i=1}^{k+d_{\max }} \lambda_{2 i} H I_{t-i}+\mu_{2 t} \\
& H I_{t}=\alpha_{3}+\sum_{i=1}^{k+d_{\max }} \beta_{3 i} l P C Y_{t-i}+\sum_{i=1}^{k+d_{\max }} \delta_{3 i} E I_{t-1}+\sum_{i=1}^{k+d_{\max }} \lambda_{3 i} H I_{t-i}+\mu_{3 t}
\end{aligned}
$$

In order to check that education does not granger cause economic growth in first equation, null hypothesis will be: $\delta_{1 i}=0 \forall_{i} \leq k$. If null hypothesis is rejected then we can infer that education granger causes economic growth. In a similar fashion all other possible causations can be checked.

\subsection{Diagnostic Tests}

In this study for conforming the validity of the fitted model three diagnostic tests are employed, i.e. LM test to check serial correlation problem, Jarque-Bera test to check normality and White heteroskedasticity test for observing the variance constancy of the residuals.

\subsection{Stability Tests}

The stability of the model is confirmed through CUSUM and CUSUMSQ proposed by Brown et al. (1975). These tests depend on cumulative sum of recursive residuals that provides analysis of parameter variations. If CUSUM cumulative sum of recursive residuals remains within the boundaries of $5 \%$ critical lines in order to ensure stability. The same is valid in CUSUMSQ.

\section{Empirical Results and Discussions}

The degree of integration is confirmed through ADF, PP and Ng-Perron tests. The results of ADF, PP and Ng-Perron are reported in Tables 2 and 3.

The results of all the three tests show that per capita output and education index both are stationary at their first difference. The results of both ADF and PP show that health index is stationary at level but Ng-Perron test reports that health index is stationary at first difference, i.e. I(1). Keeping in view that Ng-Perron test is more powerful and appropriate for small sample data set, it is decisively concluded that health index is I(1). Since all the variables are integrated of the same order, cointegration analysis is justified. 


\subsection{Cointegration Results}

After establishing degree of integration the study proceeds to estimate long-run relationship among variables. Before examining this relationship there is a need to determine optimal lag length of the model. For this purpose VAR test is applied and one lag length is selected on the basis of Akaik Information Criterion (AIC). The long-run relationship is tested through Johansen and Juselius cointegration approach. The results are reported in Table 4.

Both the trace and maximal eigen value tests reveal that there are two cointegrating vectors in the system at $5 \%$ level of significance. This suggests the existence of long-run relationship between the variables.

The results of the estimated long-run economic growth function are reported as follows:

$$
L P C Y_{t}=20.51+4.01 E I_{t}+6.35 H I_{t}
$$

t-values

The long-run coefficients of both education and health indices are aligned with theory and are also statistically significant indicating that both measures of human capital contributes in economic growth during 1974-2009.

The results of the study strongly support the view that in the long-run educated and well-nourished healthy labour force significantly contribute to economic growth. The coefficients of education and health reveal the existence of a positive and significant long-run relationship between human capital and economic growth. It may be because of an increase in workers productivity due to the proper provision of health and educational facilities to the workers. The possible factors that can be cited in this regard are increase in labour force participation especially female participation in economic activity, imparting knowledge and skills related to production process, increase in labour efficiency due to increased health facilities and improved technology, building of professional ethics and attitudes.

\subsection{Vector Error Correction Model Results}

The results of equation (1) shows that in the short-run both lagged education and health indices have no role in economic growth as both coefficients are insignificant. The significant lagged error correction term $\mathrm{EC}_{\mathrm{t}-1}$ has negative sign that is an indication of the existence of stable long-run relationship between human capital and economic growth. The feedback coefficient -0.21 shows that approximately $21 \%$ of disequilibrium is corrected in the next year.

From the results of equation (2), it can be deduced that two regressors, i.e. $D\left(L P C Y_{t-1}\right)$ and $D\left(E I_{t-1}\right)$ have established short-run relationship. The long-run relationship between the variables is evident from the negative and significant coefficient of the lagged error correction term. The fairly low coefficient of $\left(\mathrm{EC}_{\mathrm{t}-1}\right)$ shows very low speed of adjustment towards long-run equilibrium.

As per results of equation (3), two regressors have established short-run relationship whereas long-run relationship is absent due to insignificant error correction term.

\subsection{VECM Based Granger Causality Results}

The cointegration among the variables is an indication of the expected Granger causal relationship among the variables in either direction. In order to capture the long-run and short-run causality the study uses multivariate causality test. This test helps in detecting long-run causality through the significance of lagged error term while the short-run causality may be confirmed through the joint significance of $\Sigma \chi^{2}$ and individual significance of regressors. VECM based Granger causality results are reported in Table 6.

The results of the study indicate that in case of first dependent variable $\left(D\left(L P C Y_{t}\right)\right.$ lagged residual term is negative and statistically significant that reveals stable long-run relationship among the variables. The absence of short-run causality is evident from insignificant $\Sigma \chi^{2}$. For second dependent variable $\left(\mathrm{DEI}_{\mathrm{t}}\right)$ the negative and significant lagged residual term is an indication of the existence of the long-run stable equilibrium between the variables. $\Sigma \chi^{2}$ is statistically significant at $10 \%$ indicating the presence of short-run causality running from economic growth to education.

The negative and significant coefficient of lagged residual term of the dependent variable $\left(\mathrm{DHI}_{\mathrm{t}}\right)$ confirms the existence of stable long-run relationship between the variables. However, on the basis of insignificant $\Sigma \chi^{2}$, it can be concluded that there is absence of active short-run causality between the variables.

\subsection{Toda-Yamamoto Causality Results}

The main objection on VECM based causality test is that it requires pre-test assumptions of same order of integration of the variables and if these pre-test assumptions are not correctly addressed, then biases can affect the 
causality results. The present study uses Toda Yamamoto causality test which is more stable approach as compared to Error Correction Modelling (ECM). For details, see Yamada and Toda (1998).

Modified Wald test statistic, their probabilities and critical values of $\chi^{2}$ are reported in Table 7. The optimal lag length is determined as 1 through AIC and the order of integration of the variables is determined as 1 through Ng-Perron test. So the VAR (2) is estimated through SUR estimation technique.

In contrast to VECM based causality results the study finds two additional causal flows running from per capita output to health and from education to health. Hence, it can be concluded that education and economic growth both affect health. The possible rationale behind this causal relationship may be that education reduces fertility; increases awareness related to health care facilities thus improves health whereas economic growth is associated with access to better health care facilities.

\subsection{Diagnostic Tests Results}

The results of diagnostic tests are reported in Table 8 .

All diagnostic outcomes are found satisfactory thus supporting the validity of the estimates.

\subsection{CUSUM and CUSUMSQ Test of Stability}

The stability of the model is confirmed through CUSUM and CUSUMSQ as both plots stayed within the critical bounds.

\section{Conclusion and Suggestions}

The main objective of the study is to analyze the relationship between human capital and economic growth for Pakistan by using recent advances in dynamic modeling. This study investigates causality between economic growth and human capital in Pakistan using annual time series data for the period 1974-2009.

The results of this study are found consistent with the theory as well as with the past empirical research conducted on subject matter in the context of Pakistan economy. It supports significant positive impact of human capital on economic growth by confirming direct positive relationship between economic growth and measures of human capital. The existence of stable long-run relationship between economic growth and both measures of human capital is confirmed through Johansen cointegration test. Toda-Yamamoto causality test confirms the existence of three uni-directional causalities, i.e. economic growth to education index, economic growth to health index and education to health. The diagnostic outcomes are found quite satisfactory and stability of the model is confirmed through CUSUM and CUSUMSQ test. The results of the study have important implications particularly for policy makers that for achieving rapid economic growth, it is indispensable to give much emphasis to human capital.

Keeping in view the significant long-run relationship between human capital and economic growth, the study suggests that for achieving considerable and sustained economic growth there is a need to increase investment in education and health sectors. More funds as percentage of GDP may be allocated to education and health sector in line with other sectors. Furthermore, rising inflation over time calls for the need of the provision of subsidized education and health facilities to the citizens. The Ministries of Education and Health must cooperate in promoting importance of health and spreading health care information to the people on priority basis. The major limitation of the study is that it does not include any other determinant of economic growth as a regressor in the model. It is left on the interested readers to analyze the causal relationship between human capital and economic growth by including the determinants of economic growth along with human capital index.

\section{References}

Abbas, Qaiser. (2000). The role of human capital in economic growth: A comparative study of Pakistan and India. The Pakistan Development Review, 39:4, Part 2 (Winter), 451-473.

Agiomirgianakis, G., Asteriom, D., \& Monstiriotis, V. (2002). Human capital and economic growth revisited: A dynamic panel data study. IAER (International Atlantic Economic Conference), 8(3).

Barro, R. J. (1991). Economic growth in a cross section of countries. The Quarterly Journal of Economics, 106(2), 407-433. http://dx.doi.org/10.2307/2937943

Barro, R. J., \& Lee, J. W. (1993). International comparisons of educational attainment. Journal of Monetary Economics, 32(3), 363-394. http://dx.doi.org/10.1016/0304-3932(93)90023-9

Becker, Gary S. (1962). Investment in human capital: A theoretical analysis. Journal of Political Economy, 70 (Supplement), 9-49. 
Becker, Gary S. (1975). Human Capital: A Theoretical and Empirical Analysis with Special Reference to Education, $2^{\text {nd }}$ edition. Princeton University Press, Princeton, New Jersey.

Behrman, J. R., Ross, D., \& Sabot, R. (2008). Improving quality versus increasing the quantity of schooling: Estimates of rates of return from rural Pakistan. Journal of Development Economics, 85(1-2), 94-104. http://dx.doi.org/10.1016/j.jdeveco.2006.07.004

Bils, Mark, \& Klenow, Peter J. (2000). Does schooling cause growth? The American Economic Review, 90(5) December, 1160-1183.

Bloom, D. E., Canning, D., \& Sevilla, J. (2004). The effects of health on economic growth: A production function approach. World Development, 1-13.

Bosworth, Barry P., \& Collins, Susan M. (2003). The empirics of growth: An update. Brookings Papers on Economic Activity, 2.2 (September), 113-206.

Bosworth, Barry, Collins, Susan M., \& Chen, Yu-Chin. (1995). Accounting for differences in economic growth. Brookings Institution Working Paper.

Brown, R. L., Durbin, J., \& Evans, J. M. (1975). Techniques for testing the constancy of regression relationship over time. Journal of the Royal Statistical Society, 37, 149-163.

Dejong, D. A., Nankervis, J. C., Savin, N. E., \& Whiteman, C. H. (1992). Integration versus trend stationarity in time series. Econometrica, 60(2), 423-433.

Dickey, David, \& Fuller, Wayner A. (1981). Likelihood ratio statistics for autoregressive time series in a unit root. Econometrica, 49(4), 1057-1072.

Easterly, William, \& Levine, Ross. (2001). What have we learned from a decade of empirical research on growth? It's not factor accumulation: Stylized facts and growth models. World Bank Economic Review, 15:2, 177-219. http://dx.doi.org/10.1093/wber/15.2.177

Engle, R. F., \& Granger, C. W. J. (1987). Cointegration and error correction: Representation, estimation and testing. Econometrica, 55(2), 251-276. http://dx.doi.org/10.2307/1913236

Fogel, R. W. (1994). Economic growth, population health and physiology: The bearing of long-term processes on the making of economic policy. American Economic Review, 84, 369-395.

Government of Pakistan, Pakistan Economic Survey (various issues), Finance Division, Economic Advisor's Wing, Islamabad.

Jamal, H., Ashraf, I., \& Sami, F. (2003). Private returns to education: evidence from Pakistan. State Bank of Pakistan. Research Report \# 50.

Johansen, S. (1988). Statistical analysis of cointegration vectors. Journal of Economic Dynamics Control, 12(2-3), 231-254. http://dx.doi.org/10.1016/0165-1889(88)90041-3

Johansen, S., \& Juselius, K. (1990). Maximum likelihood estimation and inference on cointegration - with application to the demand for money. Oxford Bulletin of Economics and Statistics, 52(2), 169-210. http://dx.doi.org/10.1111/j.1468-0084.1990.mp52002003.x

Khan, S. Mohsin. (2005). Human capital and economic growth in Pakistan. The Pakistan Development Review, 44: 4, 455-478.

Khattak, Naeem ur Rehman, \& Khan, Jangraiz. (2012). The contribution of education to economic growth: evidence from Pakistan. International Journal of Business and Social Sciences, 3(4), Special Issue, 145-151.

Kyriacou, G. A. (1991). Level and growth effects of human capital: A cross country study of the convergence hypothesis. IDEAS.

Lucas, Robert E. (1988). On the mechanic of economic development. Journal of Monetary Economics, 22(1), 3-42. http://dx.doi.org/10.1016/0304-3932(88)90168-7

Malik, G. (2006). An examination of the relationship between health and economic growth. ICRIER, Working Paper \# 185.

Mankiw, N. Gregory, Romer, David, \& Well, David N. (1992). A contribution to the empirics of economic growth. The Quarterly Journal of Economics, 107(2), 407-437.

http://dx.doi.org/10.2307/2118477 
Mincer, Jacob. (1958). Investment in human capital and personal income distribution. Journal of Political Economy, 66(4), 281-302. http://dx.doi.org/10.1086/258055

Moser, C., \& Eliot, G. (2005). Education and Economic Growth. Uppsala: Department of Development Studies.

Nasir, Z. M., \& Nazil, H (2001). Education and Earnings in Pakistan. Pakistan Institute of Development Economics, Research Report \# 177, Islamabad.

Ng, S., \& Perron, P. (2001). Lag length selection and the construction of unit root test with good size and power. Econometrica, 69, 1519-1554. http://dx.doi.org/10.1111/1468-0262.00256

Peck, Foreman James, \& Abbas, Qaiser. (2008). Human capital in economic growth: Pakistan, 1960-2003. The Lahore Journal of Economics, 13:1 (Summer), 1-27.

Phillips, Peter, \& Perron, Pierre. (1988). Testing for a unit root in time series regression. Biometrika, 75, 335-346. http://dx.doi.org/10.1093/biomet/75.2.335

Pritchett, L. (1996). Where has all the education gone? World Bank Working Paper \# 1581, the World Bank, Washington D. C.

Qadri, Faisal Sultan, \& Waheed, Abdul. (2011). Human capital and economic growth: Time series evidence from Pakistan. Pakistan Business Review, 1, 815-833.

Rebelo, Sergio. (1991). Long-run policy analysis and long-run growth. The Journal of Political Economy, IC (500-21).

Romer, P. M. (1986). Increasing returns and long-run growth. Journal of Political Economy, 94(5), 1002-1037. http://dx.doi.org/10.1086/261420

Romer, P. M. (1990). Endogenous technological change. Journal of Political Economy, 98(5), S71-S102.

Rosenzweig, Mark R. (1990). Population growth and human capital investment: Theory and evidence. The Journal of Political Economy, 98(5).

Sachs, J. D., \& Warner, A. M. (1997). Fundamental sources of long-run economic growth. The American Economic Review, 183-188.

Schultz, Theodore W. (1961). Investment in human capital. The American Economic Review, 51, 1-17.

Schultz, Theodore W. (1971). The Role of Education and of Research. Free Press, New York.

Seebens, H., \& Wobst, P. (2003). The impact of increased school enrollment on economic growth of Tanzania. Bonn: Centre for Development Research.

Stewart, Frances, Ranis, Gustav, \& Ramirez, Alejandro. (1998). Economic growth and human development. QEH Working Paper \# 18.

Tang, C. F. (2010). The determinants of health expenditure in Malaysia: A time series analysis. MPRA Paper No. 24356.

Taniguchi, K. Wang. (2003). Nutrition intake and economic growth, Studies on the cost of hunger food and agriculture organization of US Rome, Italy.

Temple, Jonathan R. W. (2001). Generalizations that aren't? Evidence on education and growth. European Economic Review, 45:4-6 (May), 905-918. http://dx.doi.org/10.1016/S0014-2921(01)00116-7

Toda, H. Y., \& Phillips, P. C. B (1993). Vector autoregression and causality. Econometrica, 61, 1367-1393.

Toda, H. Y., \& Yamamoto, T. (1995). Statistical inferences in vector auto regressions with possibly integrated processes. Journal of Econometrics, 66, 225-250. http://dx.doi.org/10.1016/0304-4076(94)01616-8

UNDP, Human Development Report, Various issues. New York. Oxford University Press.

Weil, D. N. (2001). Accounting for the effects of health on economic growth. NBER, Working Paper, \# 11455.

World Bank (2002). Global Development Finance: Analysis and Summary Tables. Washington D.C.

Yamada, H., \& Toda, H. Y. (1998). Inference in possibly integrated vector autoregressive models: Some finite sample evidence. Journal of Econometrics, 86(1), 55-95. http://dx.doi.org/10.1016/S0304-4076(97)00109-7 
Table 1. Selected Human Capital Indicators (1980-2009) of Pakistan

\begin{tabular}{|l|c|c|c|c|c|c|}
\hline \multirow{2}{*}{ Indicators } & \multicolumn{7}{|c|}{ Years } \\
\cline { 2 - 7 } & 1980 & 1990 & 2000 & 2005 & 2008 & 2009 \\
\hline Human Development Index (HDI) & 0.31 & 0.35 & 0.41 & 0.46 & 0.48 & 0.49 \\
\hline Education Expenditure as \% of GDP & 2.12 & 1.91 & 1.83 & 2.25 & 2.47 & 2.10 \\
\hline Adult Literacy Rate (\%) 15 Years and Above & 25.72 & 33.80 & 47.10 & 49.87 & 53.69 & 55.20 \\
\hline Infant Mortality Rate (per 1,000 live births) & 116.90 & 100.70 & 84.80 & 76.40 & 71.90 & 70.50 \\
\hline Life Expectancy Total (Years) & 57.80 & 60.56 & 63.92 & 65.56 & 66.52 & 66.70 \\
\hline
\end{tabular}

Source: Human Development Reports, UNDP (various issues), World Development Indicators.

Table 2. ADF and PP Test Statistic Results 1974-2009

\begin{tabular}{|c|c|c|c|c|c|}
\hline \multirow{2}{*}{ Variables } & \multirow{2}{*}{ Levels/ First Difference } & \multicolumn{2}{|c|}{ ADF test statistic } & \multicolumn{2}{|c|}{ PP test statistic } \\
\hline & & Without trend & With trend & Without trend & With trend \\
\hline LPCY & Level & -1.05 & -2.36 & -1.70 & -2.80 \\
\hline EI & Level & 4.11 & 0.43 & 4.97 & 0.36 \\
\hline $\mathrm{HI}$ & Level & -1.34 & $-5.73^{*}$ & -1.42 & $-4.69 *$ \\
\hline$\Delta \mathrm{LPCY}$ & First Diff & $-3.60 * *$ & $-3.52 * * *$ & $-4.43 *$ & $-4.39 *$ \\
\hline$\Delta \mathrm{EI}$ & First Diff & -2.13 & $-3.71 * *$ & $-4.74 *$ & $-7.25^{*}$ \\
\hline$\Delta \mathrm{HI}$ & First Diff & $-.74 *$ & $-7.62 *$ & $-6.44 *$ & $-6.42 *$ \\
\hline \multicolumn{6}{|c|}{ Mac-Kinnon Critical Values } \\
\hline & $1 \%$ & -3.64 & -4.26 & -3.63 & -4.25 \\
\hline & $5 \%$ & -2.95 & -3.55 & -2.95 & -3.54 \\
\hline & $10 \%$ & -2.61 & -3.20 & -2.61 & -3.20 \\
\hline
\end{tabular}

Note: * shows significance at 1 percent level. ${ }^{* *}$ show significant at 5 percent level and ${ }^{* * *}$ show significant at $10 \%$ level whereas $\Delta$ is used as difference operator.

Table 3. Ng-Perron Test Results 1974-2009

\begin{tabular}{|c|c|c|c|c|c|c|c|c|}
\hline \multirow{3}{*}{ Vari-able } & \multicolumn{2}{|c|}{$\mathrm{MZ}_{\alpha}$} & \multicolumn{2}{|c|}{$\mathrm{MZ}_{\mathrm{t}}$} & \multicolumn{2}{|c|}{ MSB } & \multicolumn{2}{|c|}{ MPT } \\
\hline & \multicolumn{2}{|c|}{ Deterministic terms } & \multicolumn{2}{|c|}{ Deterministic terms } & \multicolumn{2}{|c|}{ Deterministic terms } & \multicolumn{2}{|c|}{ Deterministic terms } \\
\hline & $\mathrm{c}$ & $\mathrm{c}, \mathrm{t}$ & $\mathrm{c}$ & $\mathrm{c}, \mathrm{t}$ & $\mathrm{c}$ & $\mathrm{c}, \mathrm{t}$ & $\mathrm{c}$ & $\mathrm{c}, \mathrm{t}$ \\
\hline \multicolumn{9}{|c|}{$\mathrm{Ng}$-Perron in Levels } \\
\hline LPCY & 2.07 & -3.08 & 1.91 & -1.21 & 0.92 & 0.39 & 72.74 & 28.89 \\
\hline EI & -3.11 & -6.87 & -0.85 & -1.64 & 0.27 & 0.23 & 7.30 & 13.43 \\
\hline $\mathrm{HI}$ & -2.44 & 1.65 & -0.91 & 0.47 & 0.37 & 0.28 & 9.03 & 33.21 \\
\hline \multicolumn{9}{|c|}{ Ng-Perron in First Differences } \\
\hline$\triangle \mathrm{LPCY}$ & $-11.2 * *$ & -13.94 & $-2.27 * *$ & $-2.63^{\wedge}$ & $0.20 * *$ & 0.18 & $2.54 * *$ & $6.57^{\wedge}$ \\
\hline$\Delta \mathrm{EI}$ & -5.53 & $-15.8^{\wedge}$ & $-1.63^{\wedge}$ & $-2.8^{\wedge}$ & 0.29 & $0.17^{\wedge}$ & 4.51 & $5.79^{\wedge}$ \\
\hline$\Delta \mathrm{HI}$ & $-9358^{*}$ & 1.53 & $-684.03 *$ & 0.55 & $.0007 *$ & 0.35 & $.00007 *$ & 43.26 \\
\hline \multicolumn{9}{|c|}{ Critical values $^{\mathrm{a}}$} \\
\hline $1 \%$ & -13.8 & -23.8 & -2.58 & -3.42 & 0.17 & 0.14 & 1.78 & 4.03 \\
\hline $5 \%$ & -8.10 & -17.3 & -1.98 & -2.91 & 0.23 & 0.17 & 3.17 & 5.48 \\
\hline $10 \%$ & -5.70 & -14.2 & -1.62 & -2.62 & 0.27 & 0.18 & 4.45 & 6.67 \\
\hline
\end{tabular}

Note: $*$ denotes significance at $1 \%, * *$ denotes at $5 \%$ and ${ }^{\wedge}$ denotes at $10 \%$ significance level. a $\rightarrow$ Asymptotic critical values taken from Ng-Perron (2001, Table 1). $\mathrm{c} \rightarrow$ denotes constant and c, $\mathrm{t} \rightarrow$ denotes constant and trend. $\mathrm{MZ}_{\alpha} \rightarrow$ Modified Philips-Peron test. MZ $\rightarrow$ Modified PP t-test. MSB $\rightarrow$ Modified Sargan-Bhargava test. MPT $\rightarrow$ Modified Point Optimal test. 
Table 4. Johansen's and Juselius Cointegration Test Results 1974-2009

\begin{tabular}{|c|c|c|c|c|}
\hline Trace Stat & & & & \\
\hline Null Hypothesis & Alternative Hypothesis & Test statistic & Critical Value $(5 \%)$ & Probability** \\
\hline $\mathrm{H}_{0}: \mathrm{r} \leq 0$ & $\mathrm{H}_{\mathrm{A}}: \mathrm{r}>0$ & $44.15^{*}$ & 29.79 & 0.00 \\
\hline $\mathrm{H}_{0}: \mathrm{r} \leq 1$ & $\mathrm{H}_{\mathrm{A}}: \mathrm{r}>1$ & $15.80^{*}$ & 15.49 & 0.04 \\
\hline $\mathrm{H}_{0}: \mathrm{r} \leq 2$ & $\mathrm{H}_{\mathrm{A}}: \mathrm{r}>2$ & 0.03 & 3.84 & 0.86 \\
\hline \multicolumn{5}{|c|}{ Part 2: $\quad$ Maximal Eigen Value Statistic } \\
\hline Null Hypothesis & Alternative Hypothesis & Test statistic & Critical Value (5\%) & Probability** \\
\hline $\mathrm{H}_{0}: \mathrm{r}=0$ & $\mathrm{H}_{\mathrm{A}}: \mathrm{r}=1$ & $28.35 *$ & 21.13 & 0.00 \\
\hline $\mathrm{H}_{0}: \mathrm{r}=1$ & $\mathrm{H}_{\mathrm{A}}: \mathrm{r}=2$ & $15.77 *$ & 14.26 & 0.02 \\
\hline $\mathrm{H}_{0}: \mathrm{r}=2$ & $\mathrm{H}_{\mathrm{A}}: \mathrm{r}=3$ & 0.03 & 3.84 & 0.86 \\
\hline \multicolumn{5}{|c|}{ Part 3: $\quad$ Normalized Co-integrating Vector } \\
\hline & LPCY & Constant & EI & $\mathrm{HI}$ \\
\hline LPCY & 1.00 & 20.51 & -4.01 & -6.35 \\
\hline t-statistic & & & {$[2.29] *$} & {$[1.86] *$} \\
\hline
\end{tabular}

Note: ** P-values are taken from MacKinnon-Haug-Michelis (1999). In part 3, * denotes significance of the variable.

Table 5. VECM Estimates 1974-2009

\begin{tabular}{|c|c|c|c|}
\hline Variables & Eq.1 D(LPCY) & Eq.2 D(EI) & Eq.3 D(HI) \\
\hline Constant & 0.03 & 0.01 & 0.00 \\
& {$[1.76]^{*}$} & {$[6.57]^{*}$} & -0.04 \\
\hline $\mathrm{D}\left(\mathrm{LPCY}_{\mathrm{t}-1}\right)$ & -0.02 & -0.04 & {$[-1.74]^{*}$} \\
\hline $\mathrm{D}\left(\mathrm{EI}_{\mathrm{t}-1}\right)$ & {$[-0.15]$} & $-2.18]^{*}$ & 0.04 \\
& 0.57 & {$[-2.60]^{*}$} & -0.37 \\
\hline $\mathrm{D}\left(\mathrm{HI}_{\mathrm{t}-1}\right)$ & {$[-0.44]$} & -0.08 & {$[-1.75]^{*}$} \\
\hline$\left(\mathrm{EC}_{\mathrm{t}-1}\right)_{\mathrm{tt}}$ & {$[1.92$} & {$[-0.44]$} & -0.01 \\
& -0.21 & -0.02 & {$[-0.66]$} \\
\hline
\end{tabular}

Note: $*$ denotes significance of the variable and t-statistic values are reported in brackets.

Table 6. VECM Based Granger Causality Estimates 1974-2009

\begin{tabular}{|c|c|c|c|c|c|}
\hline \multirow{3}{*}{$\begin{array}{l}\text { Dependent } \\
\text { Variables }\end{array}$} & \multicolumn{3}{|c|}{ Independent Variables } & \multirow{2}{*}{$\left(\mathrm{EC}_{\mathrm{t}-1}\right)_{1 \mathrm{t}}$} & \multirow{3}{*}{$\Sigma \chi^{2}$} \\
\hline & DLPCY $_{t}$ & $\mathrm{DEI}_{\mathrm{t}}$ & DHI $_{t}$ & & \\
\hline & \multicolumn{3}{|c|}{$\chi^{2}\left(\alpha_{i}=0\right)$} & $t(\lambda=0)$ & \\
\hline DLPCY $_{t}$ & - & 0.19 & 2.21 & {$[-3.49]^{*}$} & 2.59 \\
\hline $\mathrm{DEI}_{\mathrm{t}}$ & $4.78^{*}$ & - & 0.19 & {$[-3.13]^{*}$} & $4.91 * * *$ \\
\hline $\mathrm{DHI}_{\mathrm{t}}$ & $3.03 * * *$ & 0.04 & - & {$[-0.66]$} & 3.20 \\
\hline \multicolumn{6}{|c|}{ Critical Values of $\chi^{2}$} \\
\hline \multicolumn{6}{|c|}{$\chi^{2}(1)$ at $1 \%=6.64, \chi^{2}(1)$ at $5 \%=3.84, \chi^{2}(1)$ at $10 \%=2.70$} \\
\hline \multicolumn{6}{|c|}{$\chi^{2}(2)$ at $1 \%=9.21, \chi^{2}(2)$ at $5 \%=5.99, \chi^{2}(2)$ at $10 \%=4.60$} \\
\hline
\end{tabular}

Note: $*$ indicates significance of the variables. 
Table 7. Toda-Yamamoto Causality Estimates 1974-2009

\begin{tabular}{|c|c|c|c|}
\hline \multirow{2}{*}{ Dependent Variables } & \multicolumn{2}{|c|}{ Sources of Causation } \\
\cline { 2 - 4 } & LPCY & EI & HI \\
\cline { 2 - 4 } & Mwald test $\left(\chi^{2}\right)$ & Mwald test $\left(\chi^{2}\right)$ & $0.71(0.39)$ \\
\hline LPCY & - & $2.27(0.13)$ & $0.30(0.58)$ \\
\hline EI & $9.14^{*}(0.00)$ & - & - \\
\hline HI & $3.05^{* * *}(0.08)$ & $6.43^{* *}(0.01)$ & \\
\hline \multicolumn{2}{|c|}{ Critical values of $\chi^{2}$} \\
\hline
\end{tabular}

Note: $*$ denotes significance at $1 \%, * *$ denotes significance at $5 \%, * * *$ denotes significance at $10 \%$. Mwald - modified wald statistic. Probability values are given in parenthesis.

Table 8. Diagnostic Test Estimates 1974-2009

\begin{tabular}{|l|c|c|l|}
\hline Test & Test statistic & Prob. & \multicolumn{1}{c|}{ Conclusion } \\
\hline LM-stat & 11.73 & 0.22 & Residuals are free from serial correlation. \\
\hline Jarque-Bera & 7.96 & 0.24 & Residuals are normally distributed. \\
\hline Chi-square & 53.43 & 0.71 & There is no heteroskedasticity. \\
\hline
\end{tabular}
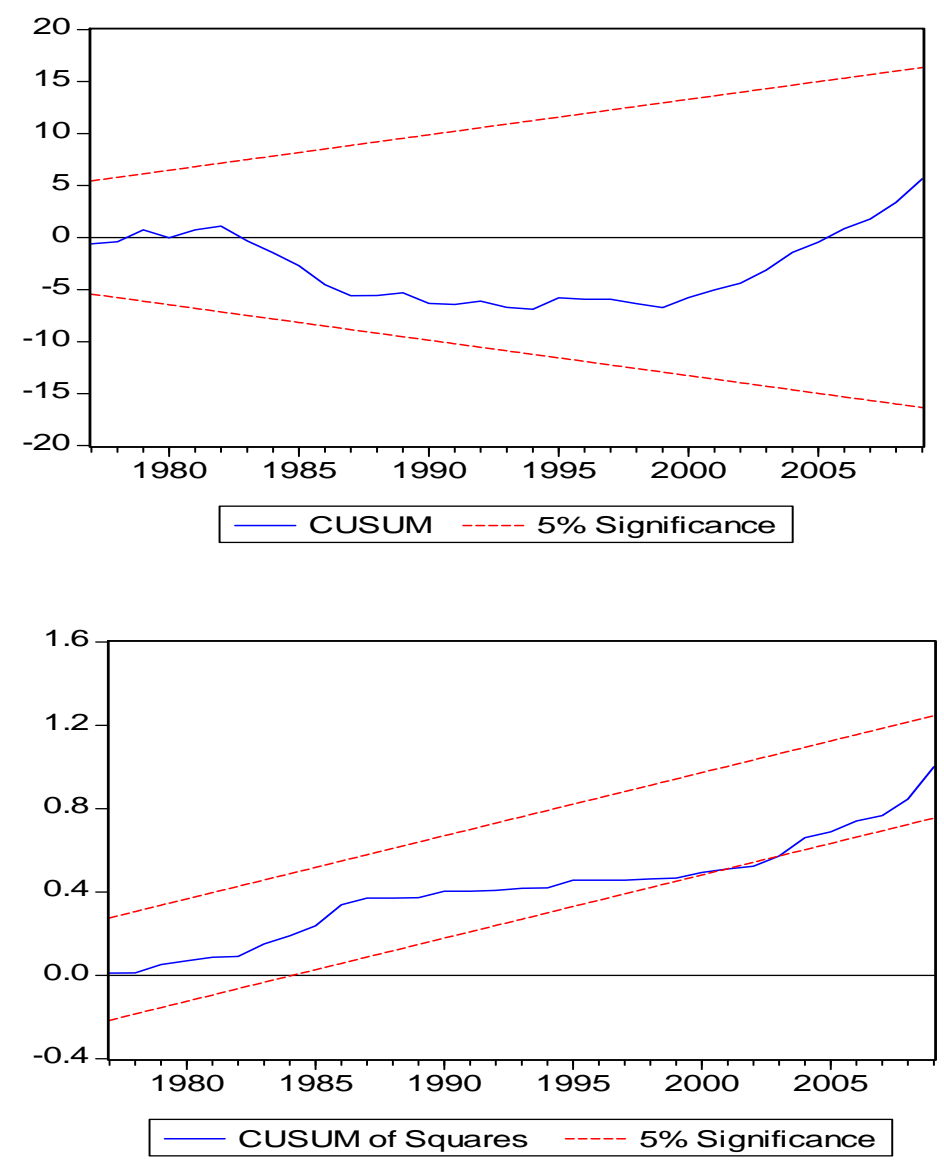

Figure 1. CUSUM and CUSUMSQ Plots 


\section{Appendix I}

Education index reflects composite measure of knowledge and it has been taken as an important ingredient of human capital along with health index. Both self-constructed indices are based on UNDP methodology given in 1999-2000. The following formula has been used for constructing both education and health indices:

$$
\begin{aligned}
& \text { Education Index }=\left[\frac{2}{3} * A L I\right]+\left[\frac{1}{3} * G E I\right] \\
& \text { Where } A L I=\frac{A L R-0}{100-0} \text { and } G E I=\frac{C G E R-0}{100-0}
\end{aligned}
$$

$\mathrm{ALI}=$ Adult literacy index, ALR $=$ Adult literacy rate, $\mathrm{GEI}=$ Gross enrollment index, $\mathrm{CGER}=$ Combined gross enrolment rates.

Education index is constructed by adding together adult literacy index (ALI) with two-third weightage and combined primary, secondary and tertiary gross enrollment index (GEI) with one-third weightage.

$$
\text { Health Index }=\left[\frac{L E-25}{85-25}\right] \quad \text { where LE }=\text { Life expectancy. }
$$

Since values of these indices lie between 0 and 1 and they are unit free, we are unable to take log of these indices. So we have used semi-log model in our study. 